\title{
Teaching Styles and Motivation in Learning Breast Stroke in Swimming
}

\author{
Achmad Sofyan Hanif ${ }^{1} \&$ Pringgo Mardesia $^{2}$ \\ ${ }^{1}$ Universitas Negeri Jakarta, Jakarta, Indonesia \\ ${ }^{2}$ Universitas Negeri Padang, Padang, Jakarta, Indonesia \\ Correspondence: Achmad Sofyan Hanif, Faculty of Sports Science, Universitas Negeri Jakarta, Kampus B, Jl. \\ Pemuda 10, Rawamangun, Jakarta 13220, Indonesia. E-mail: ashanif@unj.ac.id
}

\author{
Received: January 16, 2014 Accepted: February 20, 2014 Online Published: February 28, 2014 \\ doi:10.5539/ass.v10n5p2 \\ URL: http://dx.doi.org/10.5539/ass.v10n5p2
}

\begin{abstract}
The aim of this research is to find out the difference between teaching styles and motivation toward breast stroke skill in swimming. The sample of this research consists of 32 students who major in Physical Education Health and Recreation, State University of Padang. An experimental study with 2 X 2 factorial was designed. The data were analyzed by using ANOVA (analysis of variance) and continued with Tukey Test. The results of the research showed that (1) In general, experimental group with inclusion style has higher result than those with training style. (2) There is an interaction in the treatment between teaching style and motivation toward breast stroke skill in swimming. (3) The students who have high motivation and got treatment with inclusion style have higher result than those of high motivation in training style. (4) There is no significance difference of breast stroke skill in swim between training style and inclusion style of students who have low motivation.
\end{abstract}

Keywords: teaching styles, motivation, swimming

\section{Introduction}

Swimming course is one of the five major groups of practice subjects that becomes part of the syllabus of Physical Education, Health and Recreation Department. Swimming course contains curriculum materials that outline four swimming styles (breaststroke, crawl style, butterfly and backstroke).

Swimming skills are needed for alumni of PJKR Department, apart from teaching at schools, it can add value as an investment to open a sport industry in the field of aquatic sports. Swimming course includes a discussion of: 1) The introduction of water (breathing), 2) Gliding (front float), 3) Floating, 4) Kicking action, 5 ) Arm action, 6) Movement to take a breath (breathing), 7) Breath, kick and arm coordination, 8) Start, 9) Reversal, 10) Finish, 11) Water trod, 12) Diving, and 13) Game rules, management and organizing tournaments (PRSI 2003).

Swimming course is divided into two, namely: (1) basic swimming that consists of the teaching of breaststroke and crawl style swimming, (2) Advanced swimming that consists of backstroke and butterfly swimming, life-saving stroke and teaching methods. In basic swimming, students are expected to have a change in their behavior; one of them is to have skills of breaststroke and free style swimming, as well as to understand the history of swimming. Swimming skills are expected to lead to changes in motor skills. The change means that the students who cannot swim will be able to swim.

Factors such as students themselves, teachers/lecturers, facilities and infrastructure as well as the environment, including the style of a teacher/lecturer in delivering course materials influence the achievement of teaching and learning objectives. Understanding the variety of teaching styles has become requirements for a lecturer/teacher to (a) face the amount of students/different students, (b) learning objectives that cover all three domains of psychomotor, cognitive and social, and (c) subject matter and the context at the time of giving tasks to a specific approach.

With regard to the characteristics of the students, a lecturer applies or uses more teaching styles on the grounds of safety, uniformity, effectiveness and efficiency of time and the achievement of learning objectives of the swimming courses.

In addition to exercises teaching style, a few other teaching styles are also known. One of the teaching styles is the 
inclusion teaching style. In the inclusion teaching style, lecturers present the overall level of difficulty of the learning materials in detail because students are given the freedom to pick and choose the difficulty level from where students can begin to learn, and given the freedom to determine how many times to repeat the movements in learning a movement technique in every meeting. So with the inclusion teaching style, students are given the freedom to be creative and determine the difficulty level according to their ability. In reality however, the inclusion teaching style is still rarely used by a variety of reasons.

The efficiency and effectiveness of swimming learning also relate to the issue of self-concept, motivation, attitudes, interests and activities of student's learning. Achievement is the dream of every individual, be it is achievements in the fields of employment, education, social, art, politics, culture and others. Achievement requires a long process and requires motivation that is usually defined as a process that stimulates behavior or moves us to act.

Based on the background mentioned above, the researcher is interested in the practice of teaching style and the inclusion over the results of different swimming skills learning, and this requires a clear understanding of achievement motivation, which can be divided into (a) high achievement motivation, and (b) low achievement motivation in increasing the achievement of swimming learning results.

\section{Background Study}

\subsection{Breaststroke Swimming Skills}

Magil (1998) said skill is a word commonly used to indicate a task that has a specific goal to be achieved. For example, we say "gliding is a basic skill of swimming," or "swimming is a practice skill." These two examples are motion skills, because these skills require body movements to achieve the goal with no coercion.

Motor skills can be divided into two types, namely, fine motor skills and gross motor skills. Singer (1980) states that motor skills can be categorized into rough skills and fine skills. It is further stated that sport skills almost entirely use rough skills.

Mastery of the basic skills of breaststroke swimming technique is inseparable from the role of motion study stages. Motor learning itself, according to Schmidt (1991), is a set of processes related to training or experience that leads to a permanent change in the direction of skilled behavior. There are three stages of motor learning, namely: 1) the cognitive stage, 2) the association stage and 3) the automatization. Thus, motor learning processes are necessary in order to obtain a long lasting skill.

\subsection{Taxonomy for Educational Objectives}

According to Arends (2008), taxonomy is a tool that classifies and shows relationships among various things. In connection with the problem of learning objectives of breaststroke swimming skills, there are concepts that have been developed by experts. One of the concepts that is commonly used is the concept of Taxonomy for Educational Objectives developed by Bloom. Bloom classified educational objectives into three domains, namely cognitive, affective and psychomotor in which all of them are based on functional aspects that make up the function of human behavior.

Therefore, educational activities and objectives cannot be separated from the three domains of the taxonomy. Education is a process, in which there is a process of studying and learning. Learning is not simply gathering knowledge. Learning is a mental process within individuals, which means according to Wina Sanjaya (2008), learning is a process that occurs within individuals that we cannot observe, we can only observe the behavioral changes that are obviously seen.

Bloom's Taxonomy has been recently revised by a group of Bloom's students, (Anderson, 2001) with a new name of taxonomy for learning, teaching and assessing. The domain revised is the cognitive domain which is divided into two dimensions, namely knowledge dimension and cognitive processes dimension.

\subsection{Breaststroke Swimming Style}

Swimming is a physical (body) activity that has been practised by humans centuries ago, before humans recognize and use swimming pools like today as a place to develop human capacity in exercising. According to Corlett (1972) swimming is good for someone in self-defense when they are in water and can make this activity beneficial especially for leisure time.

Meanwhile, Donlan and Cox (1999) mentions the reason why someone does swimming activities are various, such as survival/safety (surviving from being drowning or life-saving), recreation, therapy and competition.

Breaststroke is an archaic swimming style that has existed since ancient times. This style is not extinct and today, it is one of the four swimming styles competed in the international competitions. Breaststroke has more complete 
restrictions and regulations and defined more detailed than any other styles in the rules book.

Although it is defined more detailed, breastroke is a style that is easy and convenient. Breaststroke requires regular breathing with the face buried at the time of gliding. However, breastroke can adapt to semi- vertical position very easily, by lifting the head up allowing swimmers to look forward and to talk to other swimmers. Therefore, this style is often referred to as "social" or "conversations" style.

\subsection{Teaching Style}

More researches on the process of teaching swimming need to be developed in order to generate models of effective and efficient teaching. Basically, we need a theory of universal teaching that focuses on one aspect of teaching that can be universally applied. The teaching theory should always include the integration of all phenomena and conditions of the actual teaching activity.

According to Mosston and Ashworth (2006) understanding a variety of teaching styles has become a necessity for a teacher/lecturer to (a) face the amount of different learners/students, (b) learning objectives that cover the three domains of psychomotor, cognitive and social development, and (c) subject matter and the context at the time of giving tasks to a specific approach.

Mosston and Ashworth (2006) proposed eleven teaching styles as follows: (1) the command style, (2) the practice style, (3) the reciprocal style, (4) the self-check style, (5) the inclusion style, (6) the guided discovery style, (7) the convergent discovery style, (8) the divergent production style, (9) the individual program-learner design style, (10) the learner initiated style, (11) the self-teaching style. For the purpose of this study, however, only two teaching styles were used i.e. practice and inclusion teaching style.

\subsection{Achievement Motivation}

Psychological factors also greatly affect students in any learning process, especially if the materials that have a complex level of difficulty. Students' personality, for example, will greatly influence the performance and achievements in learning.

As stated by Sudibyo (2001), personality is not easily seen and known as personality is a complex unit of soul; personality will be reflected in the ideals, characters, attitudes, attributes and actions. Thus, psychological symptoms indicated by the students' mental and personality may influence their performance as translated by their motivations and attitudes. Meanwhile, Chaplin (2001) states that personality is an intervening variable causing certain factors in an organism, which generates, manages, maintains and channels behavior towards one goal.

The term 'motivation' is defined as a process that stimulates our behavior or moves us to act, so it is the motivation that moves us to act. (Harsono 2000) says that motivation is the intention which does not appear in a person and we cannot observe it directly. Furthermore, he notes that what can observed is the behavior that is the result or manifestation of a person's self-motivation.

Therefore, motivation is a desire or passion contained within individuals over a particular activity. It is the desire that becomes the main factor that determines the individuals, whether he or she will act or not. And the motivation itself would not be able to be observed by others but the motivation usually will be reflected on one's behaviour.

\section{Methodology}

This study aimed to determine: (1) the variability in the effect of the overall teaching styles on breaststroke swimming skills, (2) the interaction between teaching styles and the achievement motivation on breaststroke swimming skills, (3) the difference between the effect of the practice teaching style and the inclusion teaching style, for students who have high achievement motivation on breaststroke swimming skills, (4) the difference between the effect of the practice teaching style and the inclusion teaching style, for students who have low achievement motivation on breaststroke swimming skills. The study was conducted over a period of 5 weeks.

The method used in this study is the experimental method with $2 \times 2$ factorial design. Sudjana (1994), states that the experimental units are grouped within cells in such a way that the experimental units within cells are relatively homogeneous and many experimental units in the cells are equal to many treatments that are being studied.

The data was analyzed by using the analysis of variance (ANOVA) with a 2 × 2 factorial design at a significant level of $\alpha=0.05$. Before performing the analysis of variance, normality test was conducted on the samples by using Liliefors; then, to look for the level of homogeneity of variance for the population, Bartlett test was used. If there is a significant interaction, Tukey's post hoc test was conducted to determine the level of significance of 
F calculated with a significance level of $\alpha=0.05$.

\section{Results}

The results of the study reject the hypothesis of the study i.e. there is no difference between the practice teaching style and the inclusion teaching style. This means that the method of practice teaching style is not better in the achievement of learning objectives of breaststroke swimming skills when compared to the inclusion teaching style; or in other words, the use of the inclusion teaching style is better than using the practice teaching style in learning achievement of breastroke swimming skills.

However, for hypothesis 3 , the results showed a significant difference between students who have high motivation taught using the practice teaching style and the inclusion teaching style in the breaststroke swimming skills. Based on these finding, it can be concluded that the variation of breaststroke swimming results in students who have high motivation is affected by the variations of the both teaching styles.

The average scores of students who have low motivation taught using the practice teaching style are higher than that of using the inclusion teaching style; however, the significance test shows no significant difference among students who have low motivation taught using the practice teaching style and the inclusion teaching style on breaststroke swimming skills. Thus, the results showed that the third hypothesis is not proven or cannot be verified. Based on these findings, it can be concluded that the variation of breaststroke swimming results for students who have low motivation is not affected by variations of both teaching styles.

There is, however, a discrepancy between the results of the study and the theoretical framework. This could be due to unforeseen possibilities that occur during the hypothesis formulation, study process and other factors. In detail, the possibilities can be discussed as follows: (1) mental state that prones to say that there is a difference between the practice teaching style and the inclusion teaching style on breaststroke swimming skills to students who have low achievement motivation; in fact, it cannot be optimized by students who have low achievement motivation. Learning pattern that tends to be classical or the teaching style that so far has been applied regularly is less appropriate for students who even have low achievement motivation. Learning pattern that tends to be classical makes students feel weird if the learning patterns lead to a more self-sufficient. (2) The students were highly dependent on the presence of lecturers' figures in the swimming courses learning, as if it is something that is not replaceable. This resulted in students who are less confident in making decision to later learn the next material that will certainly need more allocation of time and repetition. (3) The tendency of students who have low achievement motivation to attribute his success to a lack of ability. It is still seen to be attached firmly to some students who have low achievement motivation (although in this study they are conditioned not to realize that they do not have enough willpower to develop themselves) so, it is normal that the results obtained were not in accordance w the previous allegations. However, motivation is very important in the learning process, it is no exception in breaststroke swimming learning. (4) The second hypothesis shows the interaction between the teaching styles and the achievement motivation on the results of breaststroke swimming skills of students at Physical Education, Health and Recreation Department, Sports Science Faculty, Universitas Negeri Padang. Thus, it can be stated that the overall inclusion teaching style has a better effect when compared to the practice teaching style. And those who have low achievement motivation can do the exercises/learning to improve breaststroke swimming skills, but would likely be better if the learning process uses the practice teaching style.

\section{Conclusion and Suggestion}

Based on the data obtained, the hypothesis testing results and the discussion of the study results, it can be concluded that:

1) Overall, the inclusion teaching style is better than the practice teaching style on breaststroke swimming skills.

2) There is an interaction between the teaching styles and the achievement motivation on breaststroke swimming skills.

3) The inclusion teaching style is better than the practice teaching style on breaststroke swimming skills for students who have high achievement motivation.

4) There is no difference between the practice teaching style and the inclusion teaching style on breaststroke swimming skills for students who have low motivation.

\section{References}

Anderson et al. (2001). A Taxonomy for learning, teaching and assessing: A Revision of Bloom's taxonomy of educational objectives. New York: Longman.

Arends, R. (2008). Learning to Teach: Belajar untuk Mengajar. Yogyakarta: Pustaka Pelajar. 
Borg, W. R., \& Gall, M. D. (1983). Education Research: an Introduction. New York: Longman Inc.

Coker, C. A. (2004). Motor Learning and Control for Practitioners. Mexico: McGraw Hill.

Counsilman, J. E. (1977). Competitive Swimming Manual for Coaches and Swimmers. Indiana USA: Inc. Bloomington.

Donlan, A., \& Cox, P. (1999). Swimming (Royal Navy, The Royal Marines). London: Education and Youth Limited.

Harsono. (2000). Coaching dan Aspek-Aspek Psikologis Dalam Coaching. Jakarta: Tambak Kesuma.

Kirck, D., Doune, M., \& Mary, O. (2006). The Hand Book Physical Education. London SAGE Publication.

Magil, R. A. (1998). Motor Learning: Concepts and Applications. Singapore: A Division of the Mc. GrawHill. Companies.

Mangi, R., Jokl, P., \& Dayton, O. W. (1987). Sport Fitness and Training. New York: Pantheon Books, Inc.

Mosston, M. (1981). Teaching Physical Education (2nd ed.). Columbus, OH: Merrill.

Mosston, M., \& Ashwort., S. (1994). Teaching Physical Education (4th ed.). New York: Mac Millan College Publishing Inc.

Sanjaya, W. (2008). Strategi Pembelajaran (Berorientasi Standar Proses Pendidikan). Jakarta: Prenada Media Group.

Schmidt, R. A. (1988). Motor Control and Learning. Los Angeles: Human Kinetics Publishers, Inc.

Singer, R. N. (1980). Motor Learning and Human Performance. New York: MacMilan Publishing Co., In.

Sudibyo. (2001). Mental Training. Jakarta: Percetakan Solo.

Sudjana. (1994). Desain dan Analisis Eksperimen. Bandung: Tarsito.

Sugiyanto. (1993). Belajar Gerak. Jakarta: KONI Pusat.

Sugiyanto., \& Sudjarwo. (1991). Perkembangan dan Belajar Gerak. Jakarta: Depdikbud.

\section{Copyrights}

Copyright for this article is retained by the author(s), with first publication rights granted to the journal.

This is an open-access article distributed under the terms and conditions of the Creative Commons Attribution license (http://creativecommons.org/licenses/by/3.0/). 